УДК 378.011.371

DOI:

Ся Гаоян, аспірант факультету мистецтв імені Анатолія Авдієвського Національного педагогічного університету імені М.П. Драгоманова, м. Київ

\title{
ПОЛІХУДОЖНЯ ПІДГОТОВКА МАЙБУТНЬОГО ВЧИТЕЛЯ МУЗИКИ: ЗМІСТ І СТРУКТУРА, ОРІЕНТИРИ ДЛЯ ДІАГНОСТУВАННЯ
}

У статті актуалізовано поняття поліхудожньої підготовки та поліхудожньої підготовленості як їі результату. Окреслено поліхудожній потенціал музично-теоретичних дисииплін у фаховій підготовиі майбутнього вчителя музики. Показано місие курсів історії музики та аналізу музичних творів як змістово оптимальних для поліхудожньої підготовки, щзо проектується в інші музично-теоретичні та фахові дисиипліни. Описано зміст структурних компонентів поліхудожньої підготовленості в контексті вивчення історії музики та аналізу музичних творів. Обтрунтовано критерії, показники та спрогнозовано можливі рівні, передбачена варіативність проявів.

Ключові слова: майбутній учитель музики; музично-теоретичні дисципліни; поліхудожня підготовленість; компонентна структура поліхудожньої підготовленості; критерії; показники; гіпотетичні рівні.

Jim. 7.

Xia Gaoyang, Postgraduate Student of Faculty of Arts named after Anatoliy Avdiyevskiy National Mykhaylo Drahomanov Pedagogical University, Kyiv

\section{POLY-ARTISTIC PREPARATION OF FUTURE TEACHER OF MUSIC: CONTENT AND STRUCTURE, DIAGNOSTIC GUIDES}

The article examines the phenomenon of the artistic readiness of the future music teacher's personality as an integral musical and pedagogical personal quality that encompasses the cognitive, emotional, value, motivational, volitional spheres of personality, practical skills, and the ability to self-reflect. The poly-artistic potential of musicaltheoretical disciplines is revealed. It is demonstrated that the courses "History of Music" (covering sections of national music, music of near and far abroad) and "Analysis of musical works", which unites the knowledge of all musical and theoretical disciplines, are optimal for the appropriate preparation.

Examples of musical works with different artistic potential are shown: including examples of works and genres from Chinese musical culture, synthesis of arts of which, reflects the syncretism of artistic thinking (the Chinese opera, the Chinese art song). It is shown that the poly-artistic experience of the future teacher of music, obtained during the lessons of the history of music, and the analysis of musical works, is projected into other professional disciplines.

The content of structural components of poly-artistic preparedness is described (cognitive, motivational, axiological, and praxeological). The diagnostic toolkit has been developed and described: the criteria of poly-artistic preparedness (cognitive-associative, emotional-value, motivational, operational-activity) and relevant indicators.

The possible levels of poly-artistic preparedness are predicted: high (optimal-integral), medium (situationalintegral), initial (integral in elementary forms) and the possibility of a combination of forms by various indicators. Theoretically, there is a possibility of a low (indifferent) level of poly-artistic preparedness.

Keywords: a teacher of future music; musical theoretical disciplines; poly-artistic preparation; component structure of artistic readiness; criteria; indicators; hypothetical levels.

П остановка проблеми. Для сучасної освіти різних країн набувають вагомості проблеми інтегрування різних сфер знання, кожнуз яких пронизує вектор освоєння людиною комплексу життєвих компетентностей. Так само це стосується і мистецької освіти, яка $є$ універсальним чинником формування особистості, оскільки задіюе, передусім, формування світогляду і почугтєвої сфери, а отже, цінностей. Втім, насамперед, для мистецької освіти питання інтеграції пов'язано із комплексом мистецьких компетентностей, ще точніше полі художньою підготовкою вчителя, зокрема музичного мистецтва. Це пов'язано як 3 формуванням у нього цілісного мистецького світогляду, так і з викликами шкільної освіти і утвердженням ідей інтегрованої мистецької освіти, потребою у вміннях реалізувати полі художній підхід, навчаючи майбутніх учнів.

Аналіз останніх досліджень і публікацій. У психолого-педагогічних джерелах (А. Козир, Г. Падалка, О. Реброва, О. Щолокова, та ін.) детально проаналізовано зміст фахової підготовки майбутнього вчителя музики. У тому числі, достатньо уваги приділяється вивченню музичнотеоретичних дисциплін (У.Б. Демир, Ю. Локарєва 


\section{ПОЛІХУДОЖНЯПГДОТОВКА МАЙБУТНЬОГО ВЧИТЕЛЯ МУЗИКИ: ЗМІСТ ІСТРУКТУРА, ОРІЄНТИРИДЛЯДІАГНОСТУВАННЯ}

та інші). Активними є дослідження поліхудожнього вектора фахової підготовки (О. Боблієнко, О. Бузова, Ван Яюєци, Л. Масол, Т. Рейзекінд, Л. Савенкова, Б. Юсов та ін.), в яких розкривається сутність поліхудожньої компетентності, вихованості, організаційно-методичних засад поліхудожньої підготовки в контексті фахових дисциплін, розглядаються питання інтегративної мистецької освіти. Однак, поза увагою залишається поліхудожній потенціал предметів музичнотеоретичного циклу, що володіє інтегральним змістом стосовно всього комплексу фахових дисциплін.

Мета статті - окреслити сугність поліхудожньої підготовленості майбутнього вчителя музики в контексті вивчення музично-теоретичних дисциплін (історії музики та аналізу музичних творів) через виокремлення структурних компонентів феномену та методичних орієнтирів для діагностування.

Виклад основного матеріалу дослідження. Як відомо, вперше системно почав розробляти питання поліхудожнього підходу Б. Юсов, який увів поняття “поліхудожність" [7]. Філософські і методичні основи поліхудожнього підходу розроблено Л. Масол, що дало поштовх розгортанню ідеї поліцентричної інтеграції загальної мистецької освіти [3]. Отже, вчитель музики повинен уміти здійснювати поліхудожній аналіз і володіти методикою підготовки учнів до сприймання творів різних мистецтв [4]. Власне, як зазначає, Ван Яюєци, усвідомлення синкретичної природи та багатомірності художніх явищ визначило сучасні тенденції розвитку музичної освіти - акцентуацію культурологічних аспектів навчання, оволодіння узагальненими художньо-естетичними підходами, впровадження принципів взаємодії різних видів мистецтв та поліхудожнього виховання [1]. Усе це повною мірою стосується і опанування майбутнім учителем музично-теоретичних дисциплін.

У комплексі фахової підготовки майбутнього вчителя музики музично-теоретичні дисципліни представлені низкою предметів, як от: “Сольфеджіо”, “Гармонія”, “Поліфонія”, “Інструментовка”, “Оркестровка”, “Аналіз музичних творів", “Історія музики” тощо. Але саме в курси історії музики (охоплює розділи вітчизняного музичного мистецтва, музики далекого і ближнього зарубіжжя, в яких представлено музичне мистецтво минулого i сучасності, різних стильових епох, національних культур), а також аналізу музичних творів закладено поліхудожній потенціал, який збагачує фахову підготовку музиканта загалом. Зазначені курси спираються та інтегрують досвід, здобутий студентом-музикантом на заняттях з гармонії, сольфеджіо, поліфонії та інших дисциплін розділу теорії музики. Крім того, навчальний зміст курсів історії музики та аналізу музичних творів охоплює безліч творів так званих синтетичних мистецтв, у яких музика відіграє роль фундаменту, драматургічної основи: йдеться про жанри опери, балету, мюзиклу, оперети, які первинно призначені для сценічного втілення, тобто по своїй художньообразній суті невід'ємні від живопису, графіки, архітектури, хореографії, акторської майстерності тощо.

Чимало творів, що опановуються студентамимузикантами педагогічних університетів, мають програму - літературну (наприклад, “Фантастична симфонія" Г. Берліоза, “Прометей” О. Скрябіна), історичну (наприклад, "Мазепа" Ф. Ліста), живописну або архітектурно-образну ("Пагоди" К. Дебюссі); музичні твори, які цитують або використовують фольклорні теми, наприклад Симфонія № 2 Л. Ревуцького, вже викликають яскраві асоціації із народними танцями, з декоративно-прикладним мистецтвом. Музичне мистецтво часто $\epsilon$ стрижнем синтезування мистецтв, утворюючи нові форми. Можна наводити безліч прикладів.

У китайському мистецтві $є$ такий жанр, як китайська художня пісня, яка нерозривно пов'язано з найкращою китайською поезію давніх часів, з живописом, відображаючи синкретизм художнього мислення і втілюючи філософські основи світовідчуття китайського мистецтва [5]. Вистави китайської опери вважаються одним 3 найскладніших у світовому мистецтві видів сценічної народної творчості, синтезуючи жанри опери і балету (в традиційному розумінні), циркового мистецтва, драматичного театру, виконавства на народних китайських інструментах, акробатики тощо [6].

Тобто, музично-теоретичні дисципліни умовно розподіляються на поліхудожні у своїй основі та монохудожні [2]. Як раз історія музики та аналіз музичних творів і $є$ дисциплінами поліхудожніми, отже серед усіх музично-теоретичних дисциплін саме вони постають найбільш дієвими засобами поліхудожньої підготовки. Решта зазначених дисциплін (“Сольфеджіо”, “Гармонія”, "Поліфонія" та інші) можемо віднести до так званих монохудожніх. Крім того, важливо, що під час вивчення історії музики та на заняттях 3 аналізу музичних творів студенти-музиканти системно опановують музичне мистецтво через розуміння об'єктивних музично-історичних процесів, набувають ерудованості, розширюючи 


\section{ПОЛХУДОЖНЯППГОТОВКА МАЙБУТНЬОГО ВЧИТЕЛЯ МУЗИКИ: ЗМІСТ ІСТРУКТУРА, ОРІЕНТИРИ ДЛЯ ДІАГНОСТУВАННЯ}

коло знань музичних творів; навчаються орієнтуватися в історичній зумовленості музичних стилів; усвідомлюють і застосовують в інтерпретаційної діяльності принципи організації музичної мови, удосконалюють розуміння логіки музичної форми та ії невід'ємність від змісту, що пов'язано з природою художнього образу в музиці, оволодівають навичками вербальної інтерпретації творів поряд з освоєнням музичної термінології.

Поліхудожню підготовку у процесі вивчення музично-теоретичних дисциплін, передусім історії музики та аналізу музичних творів, розглядаємо як цілеспрямовану діяльність майбутнього вчителя музики - суб'єкта освітнього процесу 3 комплексного оволодіння способами взаємодії засобів різних видів мистецтва (набугтя знань про основи синтезування / інтеграції мистецтв; формування особистісних цінностей щодо творів різних видів мистецтва; набугтя практичних умінь застосування засоби різних мистецтв) для поглиблення сприймання та рефлексії музичних творів, інтерпретації синтетичних художніх образів, зокрема з музичною драматургічною основою.

Результатом поліхудожньої підготовки майбутнього вчителя музики є його поліхудожня підготовленість як інтегральна професійна якість, що виявляє себе як здатність i вмотивованість до пізнання виразних засобів різних видів мистецтва та способів їхньої взаємодії для поглиблення розуміння музичного твору; виявлення ціннісного ставлення до творів різних видів мистецтва та синтетичних творів 3 музичною драматургічною основою; готовність залучати засоби різних мистецтв для збагачення інтерпретації музичних творів.

Поліхудожня підготовленість засвідчує в майбутнього вчителя: обізнаність у видах мистецтва, в контексті яких пізнається конкретний музичний твір (культурологічноконтекстний аспект підготовленості); знання естетико-мистецтвознавчих та психологічних основ інтеграції мистецтв, що виявляється в художній та художньо-педагогічній інтерпретації творів, як належать до так званих синтетичних мистецтв 3 музичною основою (опера, балет, оперета тощо) (інтегративний підхід); емоційне прийняття необхідності поліхудожньої підготовки для власного професійного розвитку та мотивацію до набуття необхідного досвіду (аксіологічний підхід); уміння асоціювати і сформованість уявлень про способи синтезування (поєднання) засобів різних мистецтв у створенні художніх образів та практичні уміння залучати різні мистецтва для створення оригінальних художніх образів (діяльнісний підхід).
Отже, у поліхудожній підготовленості відображаються такі прояви особистісного розвитку майбутнього вчителя музики, що характеризують цю підготовленість як інтегральну якість та охоплюють його:

- когнітивну сферу (обізнаність у мистецтвах, виразних засобах та способах їх поєднання; орієнтування в естетико-мистецтвознавчому та психологічному тезаурусі щодо синтезу мистецтв);

- емочійну сферу (емоційність переживання художніх образів, створених із залученням різних видів мистецтва);

- сферу цінностей (ціннісні орієнтації щодо видів і жанрів мистецтва, які у своїй основі $\epsilon$ синтетичними; а також цінність введення таких видів мистецтва у власну музичну творчість та в майбутню педагогічну діяльність);

- мотивацію до оволодіння новими знаннями та уміннями в різних видах мистецтва;

- волю, спрямовану на визначення та подолання труднощів у процесі оволодіння знаннями та вміннями у різних видах мистецтва та мистецької (мистецько-педагогічної) діяльності;

- практичні уміння та саморефлексію набуття та здатності застосування у практичній діяльності - виконавській, аналітикоінтерпретаційній, педагогічній (практичні уміння поєднувати, експериментувати з засобами різних видів мистецтва, у тому числі й шляхом залучення цифрових технологій в естетичній площині).

Відтак, конкретизуємо структуру поліхудожньої niдготовленості, яку утворюють такі компоненти: когнітивний (знання, усвідомлення власних переживань щодо мистецтв, а також своїх знань та умінь); аксіологічний (цінності, які утворюються як емоційне переживання та рефлексія художніх образів, а також саморефлексія); мотиваційний (мотивація до художнього пізнання та застосування в майбутній педагогічній творчості); праксеологічний (уміння застосувати поліхудожні знання в інтерпретації художніх образів та передавати їх учням, уміння визначати труднощі та способи подолання).

Структурні компоненти поліхудожньої підготовленості взаємозумовлені: когнітивний компонент, охоплюючи знання та уявлення майбутнього вчителя музики щодо синтезу мистецтв, націлює його на використання поліхудожнього підходу у власній інтерпретаційній (аналітичній та виконавській) діяльності та в майбутній професії, тобто створює основу для формування праксеологічного компонента; водночас, знання та уявлення перетворюються 


\section{ПОЛІХУДОЖНЯПЦГОТОВКА МАЙБУТНЬОГО ВЧИТЕЛЯ МУЗИКИ:}

ЗМІСТ ІСТРУКТУРА, ОРІЄНТИРИ ДЛЯ ДІАГНОСТУВАННЯ

на таку основу лише за умови емоційного переживання та осмислення, тобто невід’ємні від аксіологічного компонента, що вбирає в себе емоційність переживання інформації з різних видів мистецтва та їхню рефлексію, в тому числі й рефлексію власних умінь та усвідомлення необхідності їх набуття для музичної творчості та для майбутньої педагогічної діяльності. Але сформованість аксіологічного компонента поліхудожньої підготовленості втрачатиме сенс, якщо не задіюється мотивація і до пізнання, і до використання набутого досвіду.

Таким чином, виокремлюємо критерії поліхудожньої підготовленості: когнітивноасоціативний, емоційно-ціннісний, мотиваційний, операційно-діяльнісний. Припускаємо, що зміст критеріїв не дублює компоненти поліхудожньої підготовленості, але цілісно всі критерії мають враховувати зміст усіх компонентів. А саме: когнітивно-асоиіативний критерій зіставляється 3 когнітивною сферою особистості (здатністю художнього пізнання в музичному мистецтві, в інших видах мистецтва); цүіннісно-мотиваційний критерій зіставляється 3 емоційною сферою майбутнього вчителя музики та сферою його ціннісних орієнтацій, а отже і внутрішньою мотивацією; операційно-діяльнісний критерій зіставляється із здатністю практичного застосування набутих поліхудожніх знань та умінь в інтерпретаційній діяльності.

Відповідно до критеріїв поліхудожню підготовленість заміряємо за показниками. Показниками когнітивно-асоиіативного критерію $\epsilon$ обізнаність у засобах виразності різних видів мистецтва та спільних основах інтеграції мистецтв (понятійний апарат різних видів мистецтва); знання творів синтетичних жанрів відповідно до навчального змісту музичнотеоретичних дисциплін та поза ним; здатність установлювати асоціації між засобами різних мистецтв. Показниками иіннісно-мотиваційного критерію є цілісність емоційного сприймання синтетичних художніх образів; інтерес до творів різних видів мистецтва та синтетичних творів 3 музичною драматургічною основою та вмотивованість до їхнього освоєння; розвиненість саморефлексії стосовно досягнень у полі художньому освоєнні музичних творів та творів інших мистецтв. Показниками операційнодіяльнісного критерію є здатність залучати виразні засоби різних мистецтв для самовираження у поглибленні музичного образу; уміння застосовувати засоби різних мистецтв для створення синтетичних художніх образів.

Отже, можемо спрогнозувати гіпотетичні рівні досліджуваної якості - високий (оптимальноінтегральний), середній (ситуативно-інтегральний), початковий (інтегральний 3 елементарними проявами). Припускаємо й низький рівень 3 байдужим ставленням до поліхудожнього пізнання.

Зрозуміло, що в майбутнього вчителя музики, який досяг високого (оптимально-інтегрального) рівня поліхудожньої підготовленості рівномірно $і$ повноцінно сформовані всі компоненти структури такої підготовленості. У представників із середнім (ситуативно-інтегральним рівнем) такі компоненти структури сформовані недостатньо, причому це може бути недостатня сформованість рівномірно по всіх компонентах, а можуть одні компоненти превалювати над іншими, що залежить від ситуації сприймання, мистецьких уподобань, впливу зовнішніх чинників. В осіб $з$ початковим (інтегральним 3 елементарними проявами) рівнем можуть недостатньо сформуватися всі компоненти структури, але прояви за окремими показниками бути більш яскравими; причому початковий рівень поліхудожньої підготовки ще не означає низьку підготовленість у музичному мистецтві.

Припускаємо, що майбутніх учителів музики 3 низьким (байдужим) рівнем поліхудожньої підготовленості практично немає, оскільки студенти педагогічних музичних (мистецьких) закладів вищої освіти вже здійснили вибір професії і націлені на її здобуття під час навчання. Однак, теоретично передбачити подібний ефект вважаємо необхідним, аби вчасно зафіксувати його та попередити негативні наслідки. Зрозуміло, що стосовно гіпотетично виділеного низького (байдужого) рівня поліхудожньої підготовленості в майбутнього вчителя музики фіксуємо практичну не сформованість усіх (або більшості) компонентів структури досліджуваного феномену. Знов-таки, такі особи можуть виявляти високу обізнаність у музиці, визначати пріоритети, проте не володіти мотивацією саме до поліхудожнього пізнання.

Варіантів комбінувань проявів за окремими показниками може бути набагато більше, а певні компоненти структури сформовані більшою або меншою мірою порівняно 3 іншими i характеризувати поліхудожню підготовленість 3 кількох рівневих позицій. У такому разі слід враховувати превалювання проявів за конкретними показниками над іншими для остаточного оцінювання.

Висновки і перспективи. Викладене може слугувати орієнтиром для визначення стану та динаміки поліхудожньої підготовленості майбутніх 


\section{ПОЛХУДОЖНЯППГОТОВКА МАЙБУТНЬОГО ВЧИТЕЛЯ МУЗИКИ: ЗМІСТ ІСТРУКТУРА, ОРІЕНТИРИ ДЛЯ ДІАГНОСТУВАННЯ}

учителів музики під час вивчення історії музики та аналізу музичних творів, а також як орієнтиром для визначення методичних стратегій фахової підготовки, що потребує детального розгляду.

\section{ЛІТЕРАТУРА}

1. Ван Яюєци. Формування поліхудожнього світогляду майбутнього вчителя музики як педагогічна проблема / Ван Яюєци // Наукові записки НДУ ім. М. Гоголя. Психологопедагогічні науки. - 2016. - № 3. - С.76 - 79.

2. Демир У.Б. Методика формування музичнотеоретичної підготовленості студентів у вищих музично-педагогічних закладах України. Дис. ... канд. пед..наук: 13.00.02 / Уткан Байкал Демір. Київ. НПУ імені М.П.Драгоманова, 2016.” 227 с.

3. Масол Л.М. Загальна мистецька освіта: теорія і практик: монографія / Л. Масол. - К.: Промінь, 2006. - 432 с.

4. Рейзенкінд Т. Й. Сучасні наукові методи пізнання у поліхудожній підготовці майбутнього вчителя музики / Т. Й. Рейзенкінд // Науковий часопис НПУ імені М. П. Драгоманова. Серія 14: Теорія і методика мистецької освіти. - 2010. Вип. 9. - С. $24-27$.

5. У Хуньюань. Китайская художественная песня: история и теория жанра. Дис...канд. искусствоведения: 17.00.03 / У. Хуньюань. Харьков: Харьковский национальный университет искусств имени И. П. Котляревского, 2016. $231 \mathrm{c}$.

6. Хоу Цзян. Художній світ китайської народної опери: діалог культур. Автореф. дис... канд. мистецтвознавства. 26.00.01/ Хоу Цзян/ Національна музична академія України імені П.І. Чайковського. - К., 2010. - 20 с.

7. Юсов Б. П. Эстетическое развитие как интегрированный фактор духовного формирования личности / Б.П. Юсов // Комплексное полихудожественное развитие школьников. - М., 1994. - Вып. 3. - С. 8 - 27.

\section{REFERENCES}

1. Yuetzi, V. (2016). Formuvannya polikhudozhnioho svitogliadu maibutniogo vchytelia musyky yak pedahohichna problema [Formation of the polyartistic outlook of the future teacher of music as a pedagogical problem]. The scientific notes of Nizhyn Mykola Hohol State University. The psychological and pedagogical sciences. No. 3, pp.76-79. [in Ukrainian].

2. Demyr, U. (2016). Metodyka formuvannia musychno-teoretychnoi pidhotovlenosti studentiv u vyshchykh musychno-pedahohichnykh zakladakh Ukrainy [Methodology of formation of musicaltheoretical preparedness of students in higher musical-pedagogical institutions of Ukraine]. Candidate's thesis. Kyiv. NPU, p. 227. [in Ukrainian].

3. Masol, L. (2006). Zahalna mystetska osvita: teoriia i praktyka [General artistic education: theory and practice: monograph]. Kyiv: Promin, p. 432. [in Ukrainian].

4. Raizenkind, T. (2010). Suchasni naukovi metody piznannia u polikhudozhniy pidhotovtsi maibutnioho vchytelia musyky [Modern scientific methods of cognition in the field of training of the future music teacher]. The Scientific journal of Mykhaylo Drahomanov National Pedagogical University. Series 14: The Theory and Methodology of Artistic Education. p. 14; vol. 9, pp.24 - 27. [in Ukrainian].

5. Khunyuan, U. (2016). Kitaiskaia khudozhestvennaia pesnia: istoriia i teoriia zhanra [Chinese art song: history and theory of genre]. Kharkiv, Kharkiv National University of Arts, p. 231.[in Russian].

6. Tszian, Kh. (2010). Khudozhniy svit kytaiskoi narodnoi opery: dialog kultur [Artistic world of Chinese folk opera: dialog of cultures]. Petro Chaykovskiy National Music Academy of Ukraine. Kyiv, p. 20. [in Ukrainian].

7. Yusov, B. (1994). Esteticheskoe razvitie kak integririvannyi faktor dukhovnogo formirovaniia lichnosti [Aesthetic development as integral factor of moral building of personality]. Kompleksnoe polikhudozhestvennoe razvitie shkolnikov [Complex polyart development of schoolchildren]. Moscow, Vol. 3, pp. 8 - 27. [in Russian].

Стаття надійшла до редакції 28.08.2018

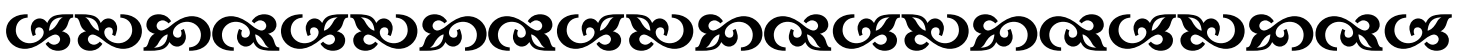

"Музика пробуджує мрію у людей усвого світу, і насамперед у ті часи, коли для мрій в життя місия взагалі не залишається”.

Рудольб Женкер

німеиький композитор, гітарист

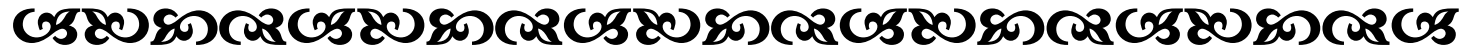

